\title{
Preliminary Phase Research Development of Learning Device Based On Problem Based Learning to Improve Mathematical Communication Ability Eighth Grade Students of Junior High School
}

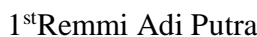 \\ Mathematics and Science Faculty \\ Universitas Negeri Padang \\ Padang, Indonesia \\ remmiadiputra9@gmail.com
}

\author{
$2^{\text {nd }}$ Yerizon \\ Mathematics and Science Faculty \\ Universitas Negeri Padang \\ Padang, Indonesia \\ yerizon@yahoo.com
}

\begin{abstract}
Based on the preliminary analysis carried out in SMP Negeri 5 Kerinci, obtained information that mathematical communication ability students have not achieved optimally. One contributing factor is the unavailability of learning device that can facilitate students to improve mathematical communication ability. This is exactly what the underlying to perform development of learning device of mathematics in the form of Plan Implementation Learning (RPP) and Worksheet Students (LKPD) based on Problem Based Learning which provides an opportunity for students to be able to find its own concept of the subject matter being studied so that students can communicate knowledge the both orally and writing. The purpose of this study is expected to obtain a learning device based on mathematics problem based learning for class VIII SMP which has the characteristics of a valid, practical and effective. Data were collected through observation, documentation, questionnaires, interviews, and test mathematical communication ability. Subject of research were students class VIII SMP Negeri 5 Kerinci. This type of research is research Plomp development model consisting of a preliminary phase of research in the form of a needs analysis, student analysis, curriculum analysis, and concept analysis. In the prototype phase is to design a product that is based LKPD and RPP based Problem Based Learning, and then conducted a formative evaluation to determine the validity and practicality of the product. In the assessment phase of assessment and test the effectiveness of the practicalities test. The results of the analysis at the preliminary research stage, then arranged the development of learning device based problem based learning to improve mathematical communication ability eight grade students of SMP. However, in this paper the researchers only explain the results of the analyzes in the preliminary research phase, which define and define the requirements needed in the development of learning device based on problem based learning so as to improve the mathematical communication ability of students.
\end{abstract}

Keywords: Learning Device, Mathematical Communication Ability, Problem Based Learning

\section{INTRODUCTION}

Mathematics is one of the basic sciences that play an important role in forming the mindset of students. The mindset can be formed in the learning of mathematics if every student is able to understand math well. In addition, mathematics also has a very important role in the development of science and technology. Therefore, to master and create technology requires a strong mastery of mathematics from an early age. Mathematics subjects need to be given to students with the ability to understand concepts, problem solving, mathematical communication, reasoning and mathematical connections.

Given the importance of mathematics in the development of science and technology, there have been many attempts by the government to solve problems in the field of mathematics education, such as improving the quality of teachers by holding seminars, developing and updating the curriculum, improving education facilities and infrastructure in schools, and providing opportunities for teachers to attend further education. The current concern is the government's effort in improving the quality of education by improving the curriculum from the Education Unit Level Curriculum (KTSP) to the curriculum of 2013. The 2013 curriculum is prepared for the people of Indonesia to have the ability to live as individuals and citizens who are faithful, productive, creative, innovative, and affective based on Permendikbud number 68 of 2013 [1].

Some mathematics learning objectives described in the Minister of Education and Culture of the Republic of Indonesia Number 58 of 2014 are: 1). Communicating ideas, reasoning and able to construct mathematical evidence using full sentences, symbols, tables, diagrams, or other media to clarify circumstances or problems. 2). Have an appreciative attitude to the usefulness of mathematics in life, which has a curiosity, attention, and interest in learning mathematics, as well as a tenacious attitude and self in solving problems [2].

Based on the objectives of mathematics learning which is explained in the Regulation of the Minister of Education and Culture of the Republic of Indonesia Number 58 of 2014, one of the capabilities that must be mastered by students is the ability of mathematical communication [2]. Mathematical communication ability is one of the most important in the process of learning mathematics [3]. Two important reasons why communication is one focus in 
learning mathematics. First mathematics is basically a language for mathematics itself, mathematics is not just a thinking tool that helps students to discover patterns, solve problems, and draw conclusions but also a tool to communicate students' thoughts about sharing ideas clearly, precisely and concisely. Both learning and teaching mathematics are social activities involving at least two parties, namely teachers and students [4].

This is similar to that expressed Mahmudi (2009) that the communication of mathematics is one of the standards of graduation competency in the field of mathematics of school students from primary to secondary education [5]. Mathematical communication ability is very important, besides the passing standard, mathematics communication is a way that students use to express an idea or idea of mathematics both with oral and written that can describe the process of thinking a person.

Mathematical communication ability is that students are able to express and interpret mathematical ideas orally, written, or demonstrating [6]. Model situations or issues use oral, written, concrete, graphic, and algebraic methods. Use reading, writing, and reviewing skills to interpret and evaluate mathematical ideas, symbols, terms and information and respond to a statement of issues in the form of opinions. The indicator of mathematical communication ability in this study refers to the NCTM 2000 which is tailored to the needs of researchers, which is limited to written communications, which are grouped into three, namely (1) to explain the idea or situation of an image that is described by his own words in writing ; (2) to declare a situation with an image; and (3) to states the situation into a mathematical model [7].

But the fact that the mathematical communication ability of the students is still not optimal, it can be seen from the result of Trends International Mathematics and Science Study (TIMSS) study and the results of the Program for International Student Assessment (PISA) test. Based on a survey of PISA in 2015 shows Indonesia is ranked at 69 from 71 countries with an average score of 386 . This device is far behind under the first Singapore countries. The assessed aspects of PISA are problem-solving abilities, reasoning and mathematical communication ability. TIMSS results in 2015 show Indonesia ranked 45 of 50 countries with 397 points. It shows that the mathematical ability of students in Indonesian is still far behind with the ability of students in other countries. In addition to the mathematical communication ability of students is still low, many students who do not usually answer the mathematics exam questions that international standards. When viewed from the tested problem, the test question is an unspecified problem, which is a problem with mathematical problems that require reasoning and understanding of concepts.

The fact that the lack of mathematical communication ability of students is also still found by researchers in the field. Based on interviews result with some students and some teachers at SMP Negeri 5 Kerinci and SMP Negeri 34 Kerinci obtained the information that students were still difficult when answering questions in the form of narrative. Students difficulties were when interpreting and understanding problems in the form of math and images. Some students can solve the problem given but they have difficulty when asked by teacher for presentation of answer result in front of class. In addition, students can solve the problem with the correct results but the steps of unstructured answers well this is a result of the lack of trained students in communicating mathematics in the form of oral and written. One example of mathematical communication problems that teachers give to students can be seen in Fig. 1.

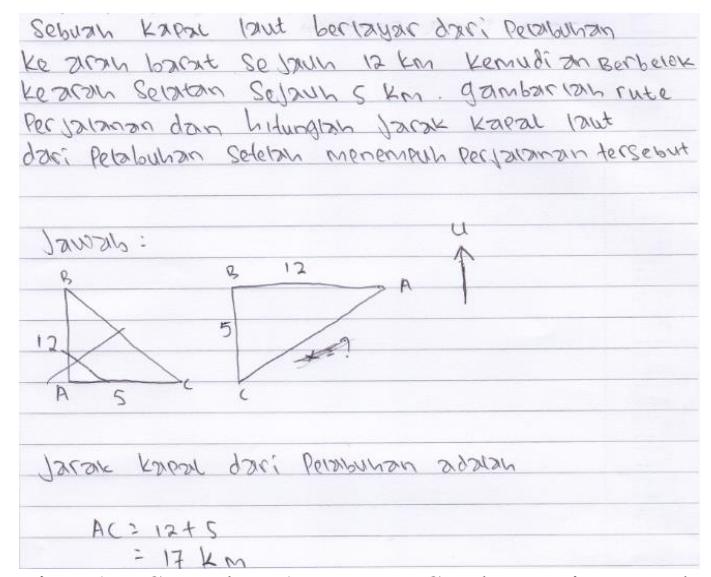

Fig 1. Sample Answers Students in Mathematical Problem Communication Ability Test

In Fig. 1 it appears that students have not been able to analyze the existing problems well. It can be seen from the way the students directly answer the problem without first identifying what the elements are known. In addition, students also have not been able to change the problem into the form of mathematical models that are expected. The completion strategy chosen by the students is also inaccurate so that the settlement procedure is false. From this answer it is also seen that students do not re-examine the truth of the results or solutions they have acquired to the initial problem or do not recalculate to believe the answer by substituting the results obtained into the known. The results showed that the mathematical communication ability of the students is still not optimal.

Based on the analysis of RPP, the activities that have been designed by the teacher have been good, but the activities described in the RPP have not helped students to find the concept of the subject matter studied directly. In the steps of the core activity seen picture, the teacher tends to provide direct explanation of the core subject matter to students, provide formulas, give examples of problems and directly to the exercise. Usually the problem given by teachers who are routine, so that students have difficulty in solving problems that vary especially the problems related to mathematical communication ability.

When students have difficulties to answer the given questions, the students tend to wait for answers from teachers so that students receive only and poorly trained in conctruction own knowledge in solving the problems studied. This is what shows the lack of active students resulting in low learning outcomes are evident from the value of mathematics learning results are still below the criteria of Minimal Completeness (KKM) is 70 .

Efforts of teachers in activating students in the learning process has been seen from providing subject matter in the form of LKPD, but unfortunately LKPD provided is not the result of the teacher development. LKPD that is currently 
used is still LKPD developed by other math teachers purchased privately owned. This is very influential because not all the contents in LKPD in accordance with the characteristics of students. From the analysis of LKPD, visible exposure to the formula of the topic of the subject matter in the absence of measures that encourage students to determine the concept of the subject matter so that students can not conctruct own knowledge.

Based on the analysis conducted on LKPD, it is seen that the presentation of the subject matter directly on the subject matter core. Students are directly given the concept of the subject matter. In the LKPD has not been supported by activities that involve students actively in making discoveries to build the concept of the subject matter being studied. Lack of involvement of students in building their own knowledge resulted students tends to memorize the formula and students easily forget the formula. This is in contrast to the original purpose of LKPD used.

Apart from the above problems, we should not only blame the teachers and students if a learning process does not run smoothly, to overcome the problems that occur in learning mathematics class, it takes an effort in selecting models and subject matter in learning. Teachers are demanded more creative, innovative, placing students not only as a learning object but also as a subject of learning and ultimately leads to a fun, fun and active learning process.

Based on the problems described above it is necessary to develop a subject matter of mathematics, namely teaching subject matter based problem-based learning that can facilitate students to conctruct own knowledge. With the existence of subject matter based problem based learning is expected to improve the mathematical communication ability of students and the ability of students in finding mathematical principles. Advantages of using Learning model problem based learning in the process of learning mathematics that is model learning problem based learning is a model of learning that presents real problems that stimulate students to learn. Providing problems in the learning model problem-based learning to strating point in learning [8]. So that with the provision of problems in the early stages of implementation is expected to construct knowledge from students.

The steps of applying the problem-based learning model are: 1) the students' orientation to the problem, 2) Organize students to learn, 3) guiding individual and group investigations, 4) developing and presenting the results, and 5 ) analyze and evaluate process and problem-solving results [9]. In the organizing phase to learn, students are required to communicate the problems presented into mathematical expressions. Then in evaluating the results of problem solving, students are also required to think objectively and rationally. In the phase of presenting the work, students are required to have confidence in delivering his work. This is in line with Selcuk stating that the problem-based learning model makes students more active in learning so as to improve students' mathematical communication ability [10]. In this problem-based learning model the students not only work alone but students work in a discussion formed in a group consisting of 4-5 people. Thus, it is expected that the implementation of problem-based learning model can influence the students' mathematical communication ability.

In the implementation of learning models in the classroom that apply the problem-based learning model, students will work in teams to solve real-world problems. Working in teams can also increase interaction among fellow students as well as increase the skills of students in the achievement of learning objectives of mathematical communication ability. This is in accordance with the opinion of Uno and Mohammad that group discussion is a way that requires students and teachers and students with other students to interact and exchange experiences and information in solving a problem [11].

With the problem-based learning model, it is expected to facilitate group work and interpersonal skills well as well as develop students' thinking skills in solving problems and can train students to be able to improve mathematical communication ability independently and by using problembased learning model in learning mathematics students are able to use the knowledge gained in solving real life problems.

Based on the results of research conducted by Research conducted by Monalia entitled "The Influence of Problem Based Learning on Communication Skills of Communication and Learning Outcomes" This study proves that problembased learning improves written communication skills and learning outcomes of students significantly [12] .

The problem-based learning model has an effect in teaching mathematics and improving students' understanding, the ability to use concepts in real life and can show that the use of problem-based learning models in learning is more effective for teaching math [13] . By adopting a problem-based learning model in mathematics learning, mathematics teachers can create a number of creative thinkers, important decision-makers, problem solvers indispensable to a competitive world.

The subject matter that will be developed will take the form of LKPD. LKPD contains steps of activities that must be done by students to find the concept of learning and exercises. As stated by Depdiknas that LKPD contains tasks to be done students, usually in the form of instructions and steps to complete a task [14]. LKPD contains a set of activities, problems or problems students will learn during the lesson. This activity sheet can also contain subject matter or steps to complete the task. LKPD can help students to be trained in self-study and hone the ability of creative thinking and critical in solving problems.

LKPD will contain questions to be answered students, with the steps of learning model problem-based learning students have the opportunity to explore its ability in presenting mathematical statement orally, written, drawing, and diagram, conjecture, mathematical manipulation, and drawing conclusions, compiling evidence, giving reasons or evidence against some solutions. In the end students will be able to communicate the idea that leads to the discovery of the concept of the subject matter being studied. Teacher assistance in the application of problem based learning method is needed in directing students and guide students in solving problems. 
In addition to LKPD-based problem-based learning for more effective learning will be accompanied by Learning Implementation Plan (RPP). RPP is a learning tool that is very important in learning, because all the activities of teachers and students have been planned in the RPP. RPP will be made of course in accordance with the concept of problem based learning. RPP is made as a teacher guide so that activities that will be done by teachers and students in class more focused and learning activities will be well

\section{METHOD}

This type of research is a development study using the Plomp model, this model consists of three phases, namely preliminary research phase, prototyping stage, and assessment stage [15]. The preliminary research phase consists of needs analysis, curriculum analysis, conceptual analysis and students analysis. Needs analysis is needed to obtain information on issues in the field of education (there are gaps between existing and expected situations). The purpose of this phase is, to obtain information on existing problems and likely to require improvement and innovation. Information gathering is done by observation of classroom learning process and interview with subject teachers.

Stage analysis of students is done to find out how the character of students. These characters include how the opinion or difficulty of students while learning mathematics, knowing how academic ability, knowing how the form of subject matter that are liked by students. For information gathering is done by interviewing teachers and distributing questionnaires to students.

In the curriculum analysis will be conducted curriculum analysis used in schools, especially for the field of study of mathematics class VIII SMP. Furthermore, at this initial stage of investigation is done with concept analysis that aims to detail and compile what subject will be learned students by applying problem based learning method.

In the prototyping stage, the prototype is formative evaluation. Phase development or prototype (prototyping stage) consists of prototype 1, self evaluation; prototype 2 expert review; prototype 3 one-to-one evaluation; prototype 4 , small group evaluation. Validation of the device is done by three lecturers of Mathematics, one lecturer of Indonesian language, and one lecturer of Educational Technology.

In the assessment phase, field testing is conducted in Grade VIII SMP Negeri 5 Kerinci to see the practicality and effectiveness. The data were collected through self evaluation sheets, validation sheets, observation sheets and interview guides, teacher response sheets and students' sheets, observation sheets of RPP implementation, and mathematical communication ability tests.

\section{RESULTS AND DISCUSSION}

This section contains results or research data, analysis of research data, answers from research questions, and analysis of findings during the study. Preliminary analysis was conducted on students of class VIII SMP Negeri 5 Kerinci and SMP Negeri 34 Kerinci. The results of the preliminary research analysis are divided into the results of needs analysis, student analysis, curriculum analysis, and concept analysis.

\section{The Results of Needs Analysis}

Stage of needs analysis is done gathering information to know the problems contained in the process of learning mathematics in school. Information gathering is done by observing the implementation of learning activities, interviewing teachers of grade VIII SMP and giving questionnaires to students about the problems that usually arise in the device of learning mathematics so it is necessary to develop it. Based on the results of observation of the implementation of learning activities in the classroom obtained the conclusion that the implementation of learning is in accordance with the RPP, only RPP that is used has not optimize in improving the ability of mathematical communication, develop the mindset of students, and direct it to be actively involved in the learning process.

Teachers have exemplified the events of everyday life or real in the step of delivering the benefits of subject matter mathematics, but at the stage of training activities to see the understanding of students, in general, the problems given are still shaped mathematically so that students become not accustomed to construct his knowledge in solving problems related to real life.

Based on the results of interviews with teachers about the obstacles that are often experienced by students in learning and subject matter used obtained the illustration that most students are still difficulties in solving problems that are applied to real life in the form of stories and lessons from LKPD less facilitate the ability of students in learning primarily to solve real-life problems in understanding problems, algebraic change, formulating problems, implementing strategies and interpreting solutions.

The presentation of problems in the LKPD used by previous teachers does not lead students to seek solutions using the thinking process but rather provides an objective, unrelated objective in everyday life that does not require students' skills in completing them. Providing problems in LKPD in general is still to train the ability to count on students so that mathematical communication ability of students is still low.

The presentation of the subject matter in the LKPD also does not lead students to construct their knowledge and does not guide students to find the process independently but contains only a set of formulas accompanied by sample questions so that students will only memorize the formula without understanding the concept of how it can happen or be obtained. Therefore, in general the presentation of LKPD content has not facilitated students to be actively involved in the process of learning mathematics in developing skills in solving problems, insights, and thinking in understanding the concepts learned and improving students' mathematical communication ability in various problems applied in life real.

Based on the results of the spreading of the questionnaire to the 58 students, it is found that LKPD has not led the students to develop their mindset in understanding the subject matter and the mathematical concept. Students need additional explanation from the teacher in understanding the subject matter in LKPD. Students still feel the difficulty in solving and solving problems in the form of stories that 
apply in real life. So that students still need LKPD that can facilitate them to participate actively in constructing their knowledge and improve their skills in solving problems related to the real world. Students want LKPD in easy-tounderstand and unambiguous language, detailed, comprehensible, interesting, and problematic explanations that are used in LKPD regarding mathematical issues in the context of everyday life.

From the result of observation, interview and questionnaire, it can be said that there are still deficiencies to RPP and LKPD, so it is necessary to provide a solution that is required a mathematics learning tool that can meet the needs of students actively learn, learning device that can train the skills of students in understanding the problems applied in real life, formulate them into mathematics or mathematical models, then solve problems to interpret the results through their own language, so as to improve the mathematical communication ability of students in learning. Learning devices that have these characteristics are Problem Based Learning (PBL).

Learning device based PBL enable students to be active in integrating knowledge and skills in solving problems by placing students to play an active role as a real-life problem solver so that students have experience learning in solving problems that exist around the students.

The stages of the PBL model are (1) Students orientation to the problem, this activity provides problems early in the learning process. Students are introduced to the problems that exist in the immediate environment of students so that students more easily accept learning with logic and can provoke curiosity students about the subject matter to be provided and expected learning activities experienced by students will be more meaningful to them. (2) Organize students to learn, in this activity students will explain how and what goals will be achieved in the learning process. Teachers will direct students to be actively involved in the entire learning process and provide responsibility to students to run directly their own learning process so that they will gain learning experience to improve students' mathematical communication ability.

(3) Guiding individual and group investigation, in this activity the students in groups solve problems related to mathematical problems applied into real life contained in LKPD and to prevent miss conception on the lesson, then the teacher will conduct guidance on the work of participants educate and direct students to use various sources of information needed in solving problems posed as in articles, subject matter that exist on the internet or visit the library to find information on other books that are related to mathematics learning at that time. (4) Develop and present the work, in this activity students will plan what to do in preparing the results of the discussion. Each group will write the results of the discussion well to be presented in front of the class and discussed together. (5) Analyze and evaluate the problem-solving process, in the last activity of the PBL, students with the teacher will reflect on the answers or the results of the discussions that have been presented by the presenter group and then evaluate the learning of the day to see the level of understanding of students in solving problems in life real by assigning a training / PR assignment.
Thus, the PBL model is not only able to train students in solving problems but also to enable students to interact positively in the learning process, work together and provide creative opportunities to students in solving problems in their own way to improve mathematical communication ability.

\section{The Result of Students Analysis}

The next step to know the character of students other than through interviews with students is also done with the division of questionnaires. Characteristic of the first students that the academic ability of students is still low is evident from the daily test of class VIII students SMP Negeri 5 Kerinci. Students who meet the above KKM values only 7 to 10 people only. The percentage of the completeness of the results of Daily Deuteronomy students VIII grade SMP Negeri 5 Kerinci academic year 2017/2018 on subject matter associated with algebraic forms such as PLDV can be presented in Table 1.

Table 1. Percentage of Daily Deuteronomy Results Complete Eighth Grade Students of SMP Negeri 5 Kerinci Academic year 2017/2018 on PLDV

\begin{tabular}{|c|c|c|c|}
\hline Classes & $\begin{array}{c}\text { Number of } \\
\text { completed } \\
\text { participants }\end{array}$ & $\begin{array}{c}\text { Number of all } \\
\text { learners }\end{array}$ & $\begin{array}{c}\text { Percent } \\
\text { completeness (\%) }\end{array}$ \\
\hline VIII a & 7 & 21 & 33.33 \\
\hline VIII b & 10 & 20 & 50 \\
\hline VIII c & 5 & 18 & 27.78 \\
\hline VIII d & 7 & 17 & 41.18 \\
\hline VIII e & 9 & 16 & 56.25 \\
\hline
\end{tabular}

Source: teachers math class VIII SMP N 5 Kerinci

The lack of understanding of students on the subject matter led many of the students who still scored below the Minimum Passing Criteria (KKM) determined for the subjects of mathematics that is 70 . Students stated that many expressed math lessons that were not fun. LKPD used is less interesting because LKPD colors such as newsprint. The problems in LKPD are very difficult to do.

Characteristics of the second students, based on interviews and observations made, it is known that students prefer to learn with peer tutors. This is seen when the learning process takes place, if students do not understand the subject matter taught by the teacher, then most students prefer to ask with friends. According to students, asking with friends who have understood can help them to understand the subject matter learned. Students tend to ask their friends, and do not dare to ask directly to the teacher.

The third characteristic is that the students are less concentrated and not even focus on the learning process delivered by the teacher. Many students who told their friends with a seat when the teacher explains the subject matter in front of the class. When teachers reprimand they pay attention to what the teacher explains, but after a few minutes they will return to tell their friends. The fourth characteristic is that most students like to group when doing an activity, such as shopping to the canteen or go to a place. This character indicates that students prefer to do an activity together.

Based on the characters encountered, the researchers feel the need to develop LKPD-based PBL that can accommodate the character possessed students in a positive direction in the 
learning process. LKPD-based PBL is a learning resource that can accommodate characteristic students of discussion, and does not focus on what the teacher describes during the learning process. Learning by using PBL based LKPD invites students to be active from the beginning of the learning process. In addition, students are also taught how the steps in solving problem-solving problems. If there are some students who prefer to learn individually, LKPD based PBL will also guide students to actively construct their knowledge independently.

\section{The Results of Curriculum Analysis}

In this study the curriculum analysis aims to determine the purpose, the content of the matter on the pattern of numbers and to determine the ability that must be possessed by students after studying the subject matter. At this stage, a review of the curriculum used in SMP Negeri 5 Kerinci is the curriculum of 2013, especially in the subject matter of class VIII number of second semester of junior high school. Analysis of the curriculum in question is the analysis of the formulation of indicators of achievement of the competence of the subject matter number pattern listed on the syllabus. No change in KI and KD has been established, but there is a change in the formulation of the indicator form in the subject matter as shown in Table 2.

Table 2. Formulation of Indicators of Competency Achievement Pattern of Class VIII SMP

\begin{tabular}{|c|c|c|}
\hline KD & $\begin{array}{c}\text { Indicators on } \\
\text { Syllabus }\end{array}$ & $\begin{array}{l}\text { New Structure } \\
\text { Indicators }\end{array}$ \\
\hline $\begin{array}{l}3.1 \text { Make } \\
\text { generalizations of the } \\
\text { patterns in the } \\
\text { sequence of numbers } \\
\text { and sequences of } \\
\text { object configurations }\end{array}$ & $\begin{array}{l}\text { - Students are able to } \\
\text { determine the next } \\
\text { term of a sequence } \\
\text { of numbers by } \\
\text { generalizing the } \\
\text { previous pattern of } \\
\text { numbers } \\
\text { - Students are able to } \\
\text { generalize the pattern }\end{array}$ & $\begin{array}{l}\text { 3.1.1. Identifies the } \\
\text { number pattern } \\
\text { 3.1.2. Determine the } \\
\text { number of first tribes of } \\
\text { arithmetic sequences } \\
\text { 3.1.3. Determine the } \\
\text { number of first n terms } \\
\text { of rows and geometry } \\
\text { series }\end{array}$ \\
\hline $\begin{array}{l}4.1 \text { Solve problems } \\
\text { related to patterns in } \\
\text { sequences of numbers } \\
\text { and sequences of } \\
\text { object configurations }\end{array}$ & $\begin{array}{l}\text { of sequence numbers } \\
\text { into an equation. } \\
\text { - Students recognize } \\
\text { various sequences of } \\
\text { numbers }\end{array}$ & $\begin{array}{l}\text { 4.1.1. Resolve the issue } \\
\text { with the pattern of } \\
\text { sequences and object } \\
\text { configuration }\end{array}$ \\
\hline
\end{tabular}

Re-formulation of indicators of achievement of competence is based on several considerations. First, basic competence 3.1 is not sufficiently measured by a single indicator so it is translated into three indicators. Second, the syllabus indicator is rearranged by separating indicators 3.1 and 4.1. This is so that learning is focused.

\section{The Result of Concepts Analysis}

Concept analysis aims to determine the subject needed in the development of learning device to achieve indicators of achievement of competence. The subject or concepts needed in the lesson are then arranged in the form of concept maps. The results of this concept analysis become the basis in the design of RPP and LKPD based problem based learning. The concept map of the matter of the number pattern can be seen in Fig. 2.

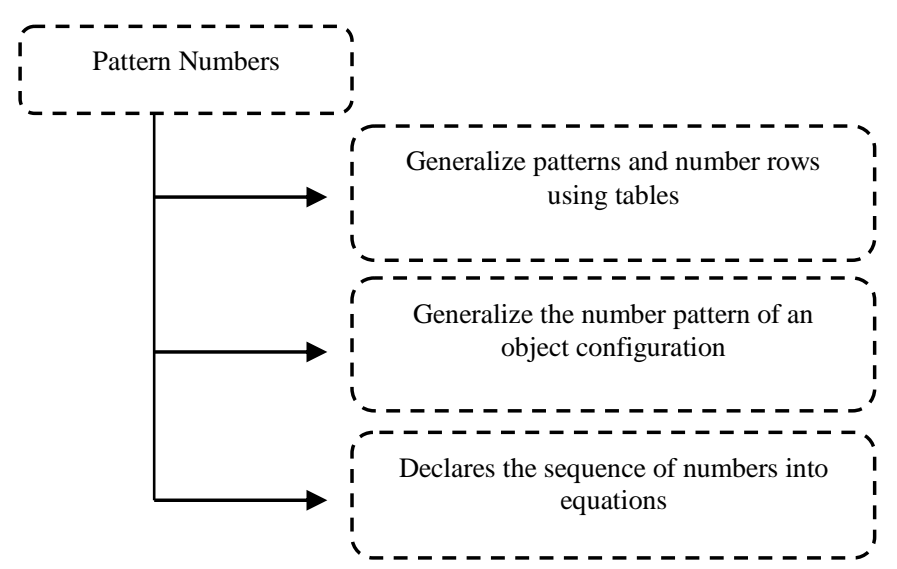

Fig. 2. Concept Map Matter of Number Patterns

\section{CONCLUSION}

This research is a development research that produces problem based learning based learning device in the form of RPP and LKPD that is valid, practical and effective to improve mathematical communication ability of class VIII class. The process of developing learning device based on problem based learning for students of class VIII SMP is carried out with Plomp development model consisting of three phases: initial investigation phase, development phase and assessment phase. In the preliminary phase carried out needs analysis, curriculum analysis, student analysis and concept analysis as a first step to do research development of learning devices. The results of the needs analysis in the form of learning device characteristics that are desirable are learning based on problem based learning device in the form of RPP and LKPD. The result of curriculum analysis is that No change in KI and KD has been established, but there is a change in the formulation of the indicator form in the subject matter. The result of student analysis is the characteristics of learning devices that are tailored to the characteristics of students. While the results of concept analysis in the form of sequence of learning subject needed in the development so that indicators of achievement of competence can be achieved.

\section{REFERENCES}

[1] Kemendikbud, Permendikbud Nomor 68 Tahun 2013 tentang KD danStruktur Kurikulum SMP/MI, Jakarta: Menteri Pendidikan dan Kebudayaan Republik Indonesia, 2013.

[2] Kemendikbud, Peraturan Menteri Pendidikan dan Kebudayaan, Nomor 58, Tahun 2014, tentang Kurikulum 2013 Sekolah Menengah Pertama (SMP) / Madrasah Tsanawiyah (MTs), 2014.

[3] Armiati. A, "Komunikasi Matematis Dan Kecerdasan Emosional", Makalah disajikan dalam Seminar Nasional Matematika dan Pendidikan Matematika 2009, Jurusan Pendidikan Matematika FMIPA UNY, 2009.

[4] Baroody. A. J, Problem Solving, Reasoning and Communicating K-8: Helping Children Think Mathematically, New York: Macmillan Publishing Company, 2007.

[5] Mahmudi. A, Komunikasi Dalam Pembelajaran Matematika, Jurnal MIPMIPA UNHALU, Accessed February 20, 2018, 12:31 AM, 2009.

[6] Shadiq. F, Kemahiran Matematika Yogyakarta : Depdiknas, 2009.

[7] NCTM, Principles and Standards for School Mathematics, Reston.Virginia: NCTM, 2009.

[8] Rusman, Model-Model Pembelajaran: Mengembangkan Profesionalisme Guru, Jakarta: Rajawali Pers, 2012.

[9] Arends. R. I, Learning To Teach (7 th) Edition, Yogjakarta: Pustaka Belajar, 2008.

[10] Hastuti. Windha Puri, Peningkatan Kemampuan Komunikasi Matematik Melalui Strategi Problem Based Learning. Artikel 
Publikasi Ilmiah. [Online]. [http://eprints.ums.ac.id/ accessed 11 November 2017], 2008.

[11] Uno, Hamzah. B, and Mohammad. Nurdin, Belajar dengan Pendekatan Pembelajaran Aktif Inovatif Lingkungan Kreatif Efektif Menarik, Jakarta: Bumi Aksara, 2015.

[12] Monalia. C, "Pengaruh Problem Based Learning terhadap Keterampilan Berkomunikasi tertulis dan Hasil Belajar", Skripsi tidak diterbitkan: FKIP Universitas Lampung, 2015.

[13] Padmavathy. R. D,'Effectiveness of Problem Based Learning in Mathematics". International Multidiscplinary e-Journal, vol 2 pp. 45 51, ISSN:2277-4262, 2013.

[14] Depdiknas, Panduan Pengembangan Bahan Ajar, Jakarta: Direktorat Jenderal Manajemen Pendidikan Dasar dan Menengah, 2008

[15] Nieveen. N, Design Approaches and Device in Education and Training, Netherlands: Kluwer Academic Publishers, 1999. 